(RESEARCH ARTICLE)

\title{
Immunological and hematological effects of Irvingia gabonensis stem bark in sodium arsenite-exposed rats
}

Efosa Godwin Ewere 1, 2, ${ }^{*}$, Ngozi Paulinus Okolie ${ }^{2}$, Jessie Idongesit Ndem ${ }^{1}$ and Samson Adewale Oyebadejo ${ }^{3}$

${ }^{1}$ Department of Biochemistry, University of Uyo, Uyo, Nigeria.

2 Department of Biochemistry, University of Benin, Nigeria.

${ }^{3}$ Department of Anatomy, University of Uyo, Uyo, Nigeria.

GSC Biological and Pharmaceutical Sciences, 2021, 15(01), 027-037

Publication history: Received on 25 February 2021; revised on 29 March 2021; accepted on 01 April 2021

Article DOI: https://doi.org/10.30574/gscbps.2021.15.1.0089

\begin{abstract}
This study investigated the effect of ethanol stem bark extract of Irvingia gabonensis (ESEIG) on sodium arsenite (SA)induced pro-inflammatory cytokines and hematological perturbations in Wistar rats. Fifty-five Wistar rats weighing $100 \mathrm{~g}$ - $179 \mathrm{~g}$ were distributed into eleven groups (n=5). Group 1 had feed and water only. Group 2 received $4.1 \mathrm{mg} / \mathrm{kg}$ body weight (kgbw) of SA. Groups 3-11 received SA and/or ESEIG. Treatment was done orally for 14 days. Interleukin$1 \beta$ (IL-1 $\beta$ ), tumor necrosis factor- $\alpha$ (TNF- $\alpha$ ), interleukin-10 (IL-10), interleukin-4 (IL-4) concentrations, hemoglobin (HB) concentration, red blood cell (RBC) count, packed cell volume (PCV), mean cell hemoglobin concentration (MCHC), mean cell hemoglobin (MCH), mean corpuscular volume (MCV), white blood cell (WBC) count and its differentials and platelet (PLT) count were used to investigate the immunological and hematological effects of ESEIG. Exposure to SA produced significant $(\mathrm{p}<0.05)$ increases in hepatic IL-1 $\beta$, TNF- $\alpha$, IL-10 and IL-4 concentrations relative to control. Administration of SA also caused significant ( $<<0.05$ ) decreases in HB, RBC, PCV, MCHC, MCH, MCV and PLT and significant $(\mathrm{p}<0.05)$ increases in WBC, lymphocytes, monocytes, eosinophils and neutrophils compared with control. Treatment with ESEIG concomitantly and 2 weeks after SA exposure, mitigated the deleterious effect of SA. However, ESEIG alone at various doses caused significant $(p<0.05)$ increases in some of the assayed parameters, compared with control. These results imply that ESEIG may be protective against SA-induced inflammation and hematological derangements in Wistar rats. Its exclusive administration on chronic basis may also be slightly toxic.
\end{abstract}

Keywords: Arsenic; Sodium arsenite; Irvingia gabonensis; Cytokines; Hematological derangements; Environmental pollutant

\section{Introduction}

Arsenic, an environmental carcinogen, contaminates groundwater in different parts of the World [1-3]. A myriad of people all over the World are exposed to arsenic via the consumption of arsenic-contaminated drinking water and food. This predisposes them to the several toxic effects of arsenic, thus compromising their health. Arsenic exposures stemming from the consumption of arsenic-contaminated drinking water have been linked to carcinogenesis among inhabitants of different countries [4,5]. Inflammation is an immunological body defense mechanism against injury, infection and allergy characterized by immigration of leukocytes and release of chemical toxins [6]. The inflammatory response is mediated by soluble factors such as cytokines [7]. However, prolonged inflammation is detrimental to health $[8,9]$. It makes the host susceptible to damaging consequences of the inflammatory response [8]. Arsenic-induced prolonged inflammation favors the development of several diseases [10]. Blood components are prone to change in relation to physiological health conditions [11]. Hematological derangements are used to determine stresses due to

\footnotetext{
* Corresponding author: Efosa Godwin Ewere

Department of Biochemistry, University of Uyo, Uyo, Nigeria.
} 
environmental and nutritional factors [12]. Arsenic and sodium arsenite have been reported to orchestrate hematological derangements $[10,13,14]$.

Irvingia gabonensis O'Rorke Baill (IG), also called bush mango, is a plant that is used in traditional and modern medicine for treatment of several illnesses [15,16]. Its stem bark is used to treat hunch back and infections in Cameroon [17] and has been reported to possess antibacterial and antifungal activities [18]. In addition, the decoction of the stem bark is utilized for treating gonorrhea, gastrointestinal and hepatic disorders and the root bark is used in poultice form to treat wounds [19]. In French Equatorial Africa, the stem bark is also used as an antidote and for treating hernias, yellow fever and dysentery [20]. The hepatoprotective, anti-diabetic, hematological and prophylactic effects of the stem bark and leaf extracts of Irvingia gabonensis in animal models have also been documented [21-24]. However, there is a paucity of information on the effects of I. gabonensis stem bark against sodium arsenite-induced immunological and hematological disturbances in animal models and this was what informed this study.

\section{Material and methods}

\subsection{Collection and Preparation of Plant Extract}

Fresh and matured stem bark of I. gabonensis O'Rorke Baill was harvested from a village in Akwa Ibom State, Nigeria. The samples were identified and authenticated by a taxonomist of the Department of Pharmacognosy and Herbal Medicine, University of Uyo, Akwa Ibom State, Nigeria. They were washed using clean water to eliminate dust and other contaminants and air-dried for 7 days at room temperature. The dried sample was then pulverized using a clean mortar and pestle, and stored in an air-tight container.

About $2800 \mathrm{~g}$ of pulverized stem bark was macerated in absolute ethanol (JHD, China) and allowed to stand for $72 \mathrm{~h}$ with intermittent stirring to ensure that the active ingredients were dissolved. The sample was filtered thrice through a clean muslin cloth and the filtrate was concentrated in stainless steel bowl using a water bath at $45^{\circ} \mathrm{C}$ to obtain a pastelike gel extract and stored in the refrigerator at $4^{\circ} \mathrm{C}$, prior to use.

\subsection{Experimental Animals}

Fifty-five (55) healthy and non-pregnant female Wistar albino rats of weighing between $100 \mathrm{~g}$ and $179 \mathrm{~g}$ were acquired from the animal house facility of Faculty of Basic Medical Sciences, University of Uyo, Nigeria. They were acclimatized for seven (7) days in the same facility under standard conditions, having free access to feed and water.

\subsection{Experimental Design}

Sequel to the seven-day acclimatization and just before treatment commenced, the experimental animals were randomly assigned to eleven (11) groups of five animals each in standard experimental animal cages and weighed using a digital weighing balance (Camry electronic scale EK5350, China) after overnight fast to obtain their initial body weights. The detailed experimental design and treatment is as represented in Table 1. The various doses of ESEIG administered, were based on the already established $\mathrm{LD}_{50}$ of the extract [25].

\subsection{Collection of Sample}

Upon completion of treatment, all experimental animals were denied feed overnight, but still had access to water ad libitum and their final body weights were taken. They were sacrificed under chloroform anesthesia using lower abdominal incision about 24 hours after the last treatment. Whole blood samples were obtained by cardiac puncture using sterile syringes and needles and collected in sterile ethylenediamine tetraacetic acid (EDTA) bottles for hematological analyses. Liver tissues were excised and rinsed with $1.15 \%$ ice cold potassium chloride (KCl) solution to remove traces of blood before weighing. The liver tissues were placed in sterile universal container and frozen prior to homogenization. 
Table 1 Experimental Design and Treatment Modalities

\begin{tabular}{|l|l|}
\hline Groups / Treatment & Dose / Duration \\
\hline 1. (Normal control) & Normal feed and water ad libitum \\
\hline 2. (Negative control) & SA at a dose of $4.1 \mathrm{mg} / \mathrm{kgbw}$ for 14 days \\
\hline 3. (Post-treatment) & $\begin{array}{l}\text { SA at a dose of } 4.1 \mathrm{mg} / \mathrm{kgbw} \text { for } 14 \text { days, followed with } \\
100 \mathrm{mg} / \mathrm{kgbw} \text { ESEIG for another } 14 \text { days }\end{array}$ \\
\hline 4. (Post-treatment) & $\begin{array}{l}\text { SA at a dose of } 4.1 \mathrm{mg} / \mathrm{kgbw} \text { for } 14 \text { days, followed with } \\
200 \mathrm{mg} / \mathrm{kgbw} \text { ESEIG for another } 14 \text { days }\end{array}$ \\
\hline 5. (Post-treatment) & $\begin{array}{l}\text { SA at a dose of } 4.1 \mathrm{mg} / \mathrm{kgbw} \text { for } 14 \text { days, followed with } \\
400 \mathrm{mg} / \mathrm{kgbw} \text { ESEIG for another } 14 \text { days }\end{array}$ \\
\hline 6. (Concomitant treatment) & $\begin{array}{l}\text { SA at a dose of } 4.1 \mathrm{mg} / \mathrm{kgbw} \text { for } 14 \text { days }+100 \mathrm{mg} / \mathrm{kgbw} \\
\text { ESEIG concomitantly for } 14 \text { days }\end{array}$ \\
\hline 7. (Concomitant treatment) & $\begin{array}{l}\text { SA at a dose of } 4.1 \mathrm{mg} / \mathrm{kgbw} \text { for } 14 \text { days }+200 \mathrm{mg} / \mathrm{kgbw} \\
\text { ESEIG concomitantly for } 14 \text { days }\end{array}$ \\
\hline 8. (Concomitant treatment) & $\begin{array}{l}\text { SA at a dose of } 4.1 \mathrm{mg} / \mathrm{kgbw} \text { for } 14 \text { days }+400 \mathrm{mg} / \mathrm{kgbw} \\
\text { ESEIG concomitantly for } 14 \text { days }\end{array}$ \\
\hline 9. (ESEIG only) & $100 \mathrm{mg} / \mathrm{kgbw}$ ESEIG only for 14 days \\
\hline 10. (ESEIG only) & $200 \mathrm{mg} / \mathrm{kgbw}$ ESEIG only for 14 days \\
\hline
\end{tabular}

ESEIG = Ethanol stem bark extract of Irvingia gabonensis; SA= Sodium arsenite; $\mathrm{mg} / \mathrm{kgbw}=$ milligram per kilogram body weight

\subsection{Homogenization of Liver Tissues}

The liver tissues of the experimental animals were homogenized as reported by Ewere et al. [26].

\subsection{Reagents and Chemicals}

Reagents / chemicals used in this study were of analytical grade and standard.

\subsection{Determination of Hepatic Pro-inflammatory and Anti-inflammatory Cytokine Levels}

Concentrations of pro-inflammatory cytokines [tumor necrosis factor- $\alpha$ (TNF- $\alpha$ ) and interleukin- $1 \beta$ (IL- $1 \beta$ )] as well as anti-inflammatory cytokines [interleukin-4 (IL-4) and interleukin-10 (IL-10)] in liver homogenates, were determined by Enzyme-linked immunosorbent assay (ELISA) using Sunlong Biotech Co. (Zhejiang, China) assay kits according to manufacturer's protocol.

\subsection{Hematological Analyses}

Red blood cell (RBC) count was carried out according to the method of Ochei and Kolhakaar [27]. Blood hemoglobin (HB) concentration was determined using the method of Tietz [28]. Wintrobe method was used in the determination of packed cell volume (PCV). Determination of White blood cell (WBC) count and its differentials was carried out according to the method of Cheesbrough [29]. Platelet (PLT) count was determined according to the method of Dacie and Lewis [30]. Red blood indices: mean cell hemoglobin (MCH), mean cell volume (MCV) and mean cell hemoglobin concentration (MCHC) were determined from RBC, PCV and haemoglobin (Hb) using the method of Jain [31].

\subsection{Statistical Analysis}

Results obtained are presented as mean \pm standard deviation (SD). They were analysed with one-way analysis of variance (ANOVA) for differences between groups using SPSS Software (IBM, version 20). Values of $p<0.05$ were considered statistically significant. 


\section{Results and discussion}

\subsection{Effect of ESEIG on Pro-inflammatory and Anti-inflammatory Cytokine Levels in Experimental Rats}

Administration of SA (group 2) caused significant $(p<0.05)$ increases in TNF- $\alpha$, IL-1 $\beta$, IL-4 and IL-10 relative to control. Post-treatment with ESEIG at various doses of 100, 200 and $400 \mathrm{mg} / \mathrm{kgbw}$, produced significant decreases in all cytokines in a dose-dependent and independent manner, compared with group 2, except IL-1 $\beta$. Concomitant treatment with ESEIG followed similar trend except IL-4 and IL-10. Treatment with ESEIG only at various doses of 100,200 and $400 \mathrm{mg} / \mathrm{kgbw}$, also produced comparable results as those of the control, except IL-4. The results of the effect of ESEIG on the immunological parameters in rats exposed to SA are presented in Table 2.

Table 2 Effect of ESEIG on Pro-Inflammatory and Anti-Inflammatory Cytokine Levels in Experimental Rats

\begin{tabular}{|l|l|l|l|l|}
\hline Groups / Treatment & TNF- $\boldsymbol{\alpha}(\mathbf{p g} / \mathbf{m L})$ & $\mathbf{I L - 1} \boldsymbol{\beta}(\mathbf{p g} / \mathbf{m L})$ & $\mathbf{I L - 4} \mathbf{( p g} / \mathbf{m L})$ & $\mathbf{I L - 1 0}(\mathbf{p g} / \mathbf{m L})$ \\
\hline 1. Control & $16.90 \pm 2.98^{\mathrm{bf}}$ & $1.68 \pm 0.34^{\text {bcdefghijk }}$ & $2.72 \pm 0.37^{\mathrm{bcefgi}}$ & $15.46 \pm 1.51^{\mathrm{bf}}$ \\
\hline 2. SA only & $22.40 \pm 2.23^{\text {acdegh }}$ & $3.58 \pm 0.57^{\mathrm{a}}$ & $5.32 \pm 0.76^{\text {acdegh }}$ & $18.08 \pm 1.29^{\mathrm{ade}}$ \\
\hline 3. Post-Treatment at $100 \mathrm{mg} / \mathrm{kg}$ & $18.06 \pm 1.59^{\mathrm{bd}}$ & $3.30 \pm 1.00^{\mathrm{a}}$ & $3.85 \pm 0.47^{\mathrm{abf}}$ & $16.04 \pm 1.74^{\mathrm{f}}$ \\
\hline 4. Post-Treatment at $200 \mathrm{mg} / \mathrm{kg}$ & $14.92 \pm 2.24^{\mathrm{bc}}$ & $2.80 \pm 0.48^{\mathrm{a}}$ & $3.36 \pm 0.62^{\mathrm{b}}$ & $15.16 \pm 1.08^{\mathrm{b}}$ \\
\hline 5. Post-Treatment at $400 \mathrm{mg} / \mathrm{kg}$ & $14.87 \pm 1.42^{\mathrm{b}}$ & $2.82 \pm 0.29^{\mathrm{a}}$ & $3.63 \pm 0.54^{\mathrm{ab}}$ & $14.19 \pm 2.87^{\mathrm{b}}$ \\
\hline 6. Concomitant at $100 \mathrm{mg} / \mathrm{kg}$ & $20.50 \pm 2.93^{\mathrm{agh}}$ & $3.60 \pm 0.26^{\mathrm{a}}$ & $4.83 \pm 0.39^{\mathrm{acgh}}$ & $20.50 \pm 0.85^{\mathrm{acgh}}$ \\
\hline 7. Concomitant at $200 \mathrm{mg} / \mathrm{kg}$ & $15.88 \pm 0.68^{\mathrm{bf}}$ & $3.10 \pm 0.48^{\mathrm{a}}$ & $3.90 \pm 0.59^{\mathrm{abf}}$ & $17.08 \pm 1.27^{\mathrm{f}}$ \\
\hline 8. Concomitant at $400 \mathrm{mg} / \mathrm{kg}$ & $15.30 \pm 3.78^{\mathrm{bf}}$ & $3.50 \pm 1.42^{\mathrm{a}}$ & $3.13 \pm 0.85^{\mathrm{bf}}$ & $16.10 \pm 1.35^{\mathrm{f}}$ \\
\hline 9. ESEIG only at $100 \mathrm{mg} / \mathrm{kg}$ & $18.30 \pm 1.80^{\mathrm{k}}$ & $3.55 \pm 0.75^{\mathrm{a}}$ & $3.65 \pm 0.15^{\mathrm{a}}$ & $14.75 \pm 0.65$ \\
\hline 10. ESEIG only at $200 \mathrm{mg} / \mathrm{kg}$ & $15.60 \pm 0.98$ & $4.03 \pm 0.80^{\mathrm{a}}$ & $3.07 \pm 0.72$ & $15.97 \pm 1.76$ \\
\hline 11. ESEIG only at $400 \mathrm{mg} / \mathrm{kg}$ & $14.03 \pm 2.75^{\mathrm{i}}$ & $3.37 \pm 0.64^{\mathrm{a}}$ & $2.77 \pm 0.80$ & $14.13 \pm 2.90$ \\
\hline
\end{tabular}

Data are expressed as mean $\pm \mathrm{SD}(\mathrm{n}=5)$; ${ }^{\mathrm{a}} p<0.05$ compared with group 1 ; ${ }^{\mathrm{b}} p<0.05$ compared with group $2{ }^{\mathrm{c}} p<0.05$ compared with group 3 ; ${ }^{\mathrm{d}} p<$

0.05 compared with group 4 ; e $p<0.05$ compared with group 5; $p<0.05$ compared with group 6; $p<0.05$ compared with group 7; h $p<0.05$ compared with group $8 ;{ }^{\mathrm{i}} p<0.05$ compared with group $9 ;{ }^{\mathrm{i}} p<0.05$ compared with group $10 ; \mathrm{k} p<0.05$ compared with group 11 ; ESEIG = Ethanol stem bark extract of Irvingia gabonensis; SA= Sodium arsenite

\subsection{Effect of ESEIG on Red Blood Cell Indices of Experimental Rats}

Results obtained showed that exposure of the experimental animals to SA (group 2) produced significant $(p<0.05)$ decreases in RBC, HB, PCV, MCH, MCHC and MCV, compared with the normal control. Post-treatment with the extract at various doses of 100, 200 and $400 \mathrm{mg} / \mathrm{kgbw}$, led to significant $(p<0.05)$ increases in RBC, PCV and MCH in a dosedependent manner as well as significant $(p<0.05)$ increases in HB and MCV in a dose-independent manner, relative to group 2 .

In addition, post-treatment with the extract at a dose of $200 \mathrm{mg} / \mathrm{kgbw}$ produced a significant $(p<0.05)$ increase in MCHC, compared with group 2. Similarly, concomitant treatment with the extract at various doses of 100,200 and 400 $\mathrm{mg} / \mathrm{kgbw}$, led to significant $(p<0.05)$ increases in all assayed red blood cell indices, compared with group 2.

Treatment with the extract alone, produced significant $(p<0.05)$ increases in RBC at doses of $200 \mathrm{mg} / \mathrm{kgbw}$ and 400 $\mathrm{mg} / \mathrm{kgbw}$, respectively and non-significant $(p>0.05)$ differences in MCH and MCHC, PCV (at doses of $200 \mathrm{mg} / \mathrm{kgbw}$ and $400 \mathrm{mg} / \mathrm{kgbw}$, respectively), relative to normal control. Treatment with the extract alone at the various doses also led to significant $(p<0.05$ ) decreases in HB and MCV (at doses of at doses of $100 \mathrm{mg} / \mathrm{kgbw}$ and $400 \mathrm{mg} / \mathrm{kgbw}$, respectively) compared with the normal control. The detailed results are presented in Table 3. 
Table 3 Effect of ESEIG on Red Blood Cell Indices of Experimental Rats

\begin{tabular}{|c|c|c|c|c|c|c|}
\hline Groups / Treatment & $\begin{array}{l}\text { RBC } \\
\left(\times 10^{6} / \mu L\right)\end{array}$ & HB (g/dL) & PCV (\%) & $\begin{array}{l}\text { MCH } \\
\text { (pg/cell) }\end{array}$ & MCHC (g/dL) & $\operatorname{MCV}\left(\mu \mathrm{m}^{3}\right)$ \\
\hline 1. Control & $7.50 \pm 0.52^{\mathrm{bfhjk}}$ & $14.04 \pm 1.01^{\text {bcefghijk }}$ & $41.56 \pm 4.36^{\text {bcdefi }}$ & $18.46 \pm 0.54 \mathrm{bcdf}$ & $33.74 \pm 1.86^{\mathrm{bch}}$ & $50.28 \pm 1.79$ bcefghik \\
\hline 2. SA only & $3.95 \pm 1.32^{\text {acdefgh }}$ & $8.11 \pm 1.22^{\text {acdefgh }}$ & $22.15 \pm 5.29^{\text {acdegh }}$ & $8.94 \pm 1.71$ acdefgh & $23.03 \pm 4.54$ adefgh & $30.73 \pm 3.31$ acdefgh \\
\hline $\begin{array}{l}\text { 3. Post-Treatment at } \\
100 \mathrm{mg} / \mathrm{kg}\end{array}$ & $7.53 \pm 0.45^{\mathrm{bf}}$ & $12.57 \pm 0.63^{\mathrm{ab}}$ & $27.96 \pm 5.18^{\text {abe }}$ & $15.56 \pm 1.82^{\mathrm{abf}}$ & $20.26 \pm 4.78^{\text {adef }}$ & $42.02 \pm 1.52^{\mathrm{ab}}$ \\
\hline $\begin{array}{l}\text { 4. Post-Treatment at } \\
200 \mathrm{mg} / \mathrm{kg}\end{array}$ & $7.67 \pm 0.36^{b}$ & $13.37 \pm 0.73^{\text {beg }}$ & $30.60 \pm 6.25^{\text {abeg }}$ & $16.53 \pm 1.25^{\mathrm{ab}}$ & $34.80 \pm 3.16^{\mathrm{bc}}$ & $43.20 \pm 2.45^{\mathrm{ab}}$ \\
\hline $\begin{array}{l}\text { 5. Post-Treatment at } \\
400 \mathrm{mg} / \mathrm{kg}\end{array}$ & $8.13 \pm 0.68^{\text {bh }}$ & $12.10 \pm 1.14^{\mathrm{abd}}$ & $36.78 \pm 3.63^{\mathrm{bcd}}$ & $17.20 \pm 1.82^{\mathrm{b}}$ & $32.90 \pm 5.88 b^{c h}$ & $42.90 \pm 1.94^{\mathrm{ab}}$ \\
\hline $\begin{array}{l}\text { 6. Concomitant at } 100 \\
\mathrm{mg} / \mathrm{kg}\end{array}$ & $8.76 \pm 0.62^{\mathrm{abc}}$ & $12.04 \pm 0.65^{\mathrm{ab}}$ & $27.65 \pm 2.64^{\text {agh }}$ & $12.16 \pm 1.90^{\mathrm{abcgh}}$ & $33.68 \pm 1.70^{\mathrm{bc}}$ & $43.78 \pm 4.49 \mathrm{ab}$ \\
\hline $\begin{array}{l}\text { 7. Concomitant at } 200 \\
\mathrm{mg} / \mathrm{kg}\end{array}$ & $8.24 \pm 0.97^{b}$ & $11.19 \pm 0.93^{\mathrm{abd}}$ & $36.58 \pm 1.96^{\text {bdf }}$ & $16.90 \pm 1.52^{\mathrm{bf}}$ & $38.95 \pm 1.96^{\mathrm{bx}}$ & $45.10 \pm 4.17 \mathrm{ab}$ \\
\hline $\begin{array}{l}\text { 8. Concomitant at } 400 \\
\mathrm{mg} / \mathrm{kg}\end{array}$ & $9.26 \pm 0.30^{\text {abe }}$ & $12.32 \pm 1.74^{\mathrm{ab}}$ & $38.87 \pm 1.66^{\mathrm{bf}}$ & $18.01 \pm 1.06^{\mathrm{bf}}$ & $42.53 \pm 13.69$ abef & $41.43 \pm 1.90^{\mathrm{ab}}$ \\
\hline $\begin{array}{l}\text { 9. ESEIG only at } 100 \\
\mathrm{mg} / \mathrm{kg}\end{array}$ & $7.90 \pm 0.60$ & $10.46 \pm 0.18^{\mathrm{ajk}}$ & $27.90 \pm 1.30^{\mathrm{ajk}}$ & $18.11 \pm 0.25$ & $35.45 \pm 3.65$ & $43.35 \pm 1.75^{a}$ \\
\hline $\begin{array}{l}\text { 10. ESEIG only at } 200 \\
\mathrm{mg} / \mathrm{kg}\end{array}$ & $8.57 \pm 0.56^{a}$ & $12.25 \pm 0.46^{\mathrm{ai}}$ & $43.40 \pm 4.80^{\mathrm{i}}$ & $18.12 \pm 0.20$ & $37.87 \pm 4.46$ & $47.13 \pm 0.49$ \\
\hline $\begin{array}{l}\text { 11. ESEIG only at } 400 \\
\mathrm{mg} / \mathrm{kg}\end{array}$ & $9.06 \pm 1.01^{\mathrm{a}}$ & $12.66 \pm 0.46^{\mathrm{ai}}$ & $45.00 \pm 2.65^{\mathrm{i}}$ & $18.42 \pm 0.78$ & $38.00 \pm 1.44$ & $44.90 \pm 4.18^{\mathrm{a}}$ \\
\hline
\end{tabular}

Data are expressed as mean $\pm \mathrm{SD}(\mathrm{n}=5)$; $\mathrm{a} p<0.05$ compared with group 1 ; $\mathrm{b} p<0.05$ compared with group $2 \mathrm{c} p<0.05$ compared with group 3 ; d $p<0.05$ compared with group 4; e $p<0.05$ compared with group 5; $p<0.05$ compared with group 6; ${ }^{\mathrm{g}} p<0.05$ compared with group 7; $\mathrm{h} p<0.05$ compared with group 8 ; i $p<0.05$ compared with group 9; $p<0.05$ compared with group 10 ; ${ }^{\mathrm{k}} p<0.05$ compared with group 11; ESEIG = Ethanol stem bark extract of Irvingia gabonensis; SA= Sodium arsenite 
Table 4 Effect of Ethanol Stem Bark Extract of Irvingia gabonensis 0’Rorke Baill on Platelets, White Blood Cell Count and Its Differentials of Experimental Rats

\begin{tabular}{|c|c|c|c|c|c|c|c|}
\hline $\begin{array}{l}\text { Groups } \\
\text { Treatment }\end{array}$ & 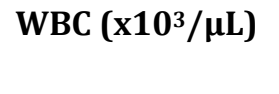 & $\begin{array}{l}\text { Platelets } \\
\left.10^{3} / \mu \mathrm{L}\right)\end{array}$ & $\begin{array}{l}\text { Lymphocytes } \\
\text { (\%) }\end{array}$ & Monocytes (\%) & $\begin{array}{l}\text { Basophils } \\
(\%)\end{array}$ & $\begin{array}{l}\text { Eosinophils } \\
\text { (\%) }\end{array}$ & Neutrophils (\%) \\
\hline Control & $3.58 \pm 0.71^{\text {bcdefghijk }}$ & $\begin{array}{l}700.60 \pm 28.52 \\
\text { bcdefghijk }\end{array}$ & $\begin{array}{l}37.40 \pm 4.51 \\
\text { bcdefghijk }\end{array}$ & $\begin{array}{l}24.80 \pm 4.09 \\
\text { bcdefghijk }\end{array}$ & $0.00 \pm 0.00$ & $\begin{array}{l}0.80 \pm 0.84 \\
\text { bcdefghijk }\end{array}$ & $47.20 \pm 3.90^{\text {bcdefgi }}$ \\
\hline SA only & $8.04 \pm 1.46^{\text {acdegh }}$ & $334.75 \pm 87.79$ acdefgh & $78.50 \pm 4.20$ acdefgh & $49.50 \pm 12.71^{a}$ & $0.50 \pm 0.58$ & $\begin{array}{l}12.75 \pm 0.96 \\
\text { acdefgh }\end{array}$ & $80.75 \pm 4.03$ acdefgh \\
\hline $\begin{array}{l}\text { Post-Treatment } \\
\text { at } 100 \mathrm{mg} / \mathrm{kg}\end{array}$ & $6.66 \pm 0.63^{\mathrm{abf}}$ & $439.40 \pm 54.23^{\mathrm{abf}}$ & $65.00 \pm 8.75^{\text {abdef }}$ & $49.00 \pm 5.24^{a}$ & $0.40 \pm 0.55$ & $10.00 \pm 0.71^{\mathrm{ab}}$ & $69.00 \pm 4.58^{\mathrm{abd}}$ \\
\hline $\begin{array}{l}\text { Post-Treatment } \\
\text { at } 200 \mathrm{mg} / \mathrm{kg}\end{array}$ & $6.49 \pm 0.46^{\mathrm{ab}}$ & $459.20 \pm 62.89 \mathrm{abg}$ & $58.20 \pm 4.87 \mathrm{abc}$ & $45.60 \pm 3.65^{\mathrm{a}}$ & $0.20 \pm 0.45$ & $8.60 \pm 1.14^{\mathrm{ab}}$ & $63.00 \pm 6.75^{\mathrm{abc}}$ \\
\hline $\begin{array}{l}\text { Post-Treatment } \\
\text { at } 400 \mathrm{mg} / \mathrm{kg}\end{array}$ & $6.92 \pm 0.70^{\mathrm{ab}}$ & $486.50 \pm 46.62^{\mathrm{ab}}$ & $53.25 \pm 3.20^{\mathrm{abc}}$ & $48.75 \pm 2.99^{a}$ & $0.25 \pm 0.50$ & $8.25 \pm 1.26^{a b}$ & $63.25 \pm 1.71^{\mathrm{abh}}$ \\
\hline $\begin{array}{l}\text { Concomitant at } \\
100 \mathrm{mg} / \mathrm{kg}\end{array}$ & $7.66 \pm 0.97$ ach & $527.50 \pm 48.79 \mathrm{abc}$ & $54.50 \pm 3.11^{\mathrm{abc}}$ & $54.00 \pm 6.38^{a}$ & $0.50 \pm 0.58$ & $10.50 \pm 1.29 \mathrm{abh}$ & $66.50 \pm 3.70^{\text {abh }}$ \\
\hline $\begin{array}{l}\text { Concomitant at } \\
200 \mathrm{mg} / \mathrm{kg}\end{array}$ & $6.84 \pm 0.60^{\mathrm{ab}}$ & $541.75 \pm 26.29$ abd & $55.00 \pm 6.68^{\mathrm{ab}}$ & $47.50 \pm 3.70^{\mathrm{a}}$ & $0.00 \pm 0.00$ & $8.75 \pm 0.96^{\mathrm{ab}}$ & $60.00 \pm 3.74 \mathrm{abh}$ \\
\hline $\begin{array}{l}\text { Concomitant at } \\
400 \mathrm{mg} / \mathrm{kg}\end{array}$ & $5.96 \pm 0.19 \mathrm{abf}$ & $544.33 \pm 52.99 \mathrm{ab}$ & $52.33 \pm 4.04^{\mathrm{ab}}$ & $45.33 \pm 4.93^{\mathrm{a}}$ & $0.00 \pm 0.00$ & $8.00 \pm 1.00^{\mathrm{abf}}$ & $52.00 \pm 2.65^{\text {befg }}$ \\
\hline $\begin{array}{l}\text { ESEIG only at } 100 \\
\mathrm{mg} / \mathrm{kg}\end{array}$ & $5.31 \pm 0.05^{\mathrm{a}}$ & $570.67 \pm 4.51^{\text {a }}$ & $51.00 \pm 2.00^{\mathrm{a}}$ & $47.67 \pm 1.53^{\mathrm{a}}$ & $0.33 \pm 0.58$ & $9.00 \pm 2.00^{\mathrm{ak}}$ & $63.00 \pm 5.00^{\mathrm{ajk}}$ \\
\hline $\begin{array}{l}\text { ESEIG only at } 200 \\
\mathrm{mg} / \mathrm{kg}\end{array}$ & $5.78 \pm 0.34^{\mathrm{a}}$ & $549.67 \pm 53.27^{a}$ & $54.33 \pm 4.73^{\mathrm{a}}$ & $41.00 \pm 4.36^{\mathrm{a}}$ & $0.33 \pm 0.58$ & $8.33 \pm 2.52^{\mathrm{a}}$ & $53.00 \pm 7.00^{\mathrm{i}}$ \\
\hline $\begin{array}{l}\text { ESEIG only at } 400 \\
\mathrm{mg} / \mathrm{kg}\end{array}$ & $5.48 \pm 0.44^{\mathrm{a}}$ & $606.00 \pm 36.76^{a}$ & $49.00 \pm 5.29^{a}$ & $42.67 \pm 3.51^{\mathrm{a}}$ & $0.00 \pm 0.00$ & $6.67 \pm 2.08^{\mathrm{ai}}$ & $52.67 \pm 4.73^{\mathrm{i}}$ \\
\hline
\end{tabular}

Data are expressed as mean $\pm \mathrm{SD}(\mathrm{n}=5)$; ${ }^{\mathrm{a}} p<0.05$ compared with group 1 ; $^{\mathrm{b}} p<0.05$ compared with group $2^{\mathrm{c}} p<0.05$ compared with group 3 ; ${ }^{\mathrm{d}} p<0.05$ compared with group 4 ; ${ }^{\mathrm{e}} p<0.05$ compared with group 5 ; f $<0.05$ compared with group 6 ; g $p<0.05$ compared with group 7 ; ${ }^{\text {h }} p<0.05$ compared with group 8 ; ${ }^{i} p<0.05$ compared with group 9 ; $p<0.05$ compared with group 10 ; ${ }^{\mathrm{k}} p<0.05$ compared with group 11; ESEIG = Ethanol stem bark extract of Irvingia gabonensis; $\mathrm{SA}=$ Sodium arsenite 


\subsection{Effect of ESEIG on Platelet Count, White Blood Cell Count and its Differentials of Experimental Rats}

Administration of sodium arsenite to the experimental rats (group 2) produced significant $(p<0.05)$ increases in WBC, lymphocyte (LYM), monocyte (MON), eosinophil (EOS) and neutrophil (NEU) counts and a significant ( $p<0.05$ ) decrease in PLT count, compared with the normal control. Post-treatment with the extract at various doses of 100, 200 and $400 \mathrm{mg} / \mathrm{kgbw}$, led to significant $(p<0.05)$ decreases in WBC, LYM, EOS and NEU in a dose-dependent and independent manner, compared with group 2. Post-treatment with extract at the various doses, also culminated in significant $(p<0.05)$ increases in PLT count in a dose-dependent manner, compared with group 2. Similar trends were observed for the concomitantly-treated rats, compared with group 2 . Treatment with extract also produced insignificant differences $(p>0.05)$ in MON count when the treated groups were compared. There were no significant $(p>0.05)$ differences in BAS count across all experimental groups.

Treatment with extract alone at various doses of 100, 200 and $400 \mathrm{mg} / \mathrm{kgbw}$, culminated in significant $(p<0.05)$ increases in WBC, LYM MON, EOS and NEU counts and significant $(p<0.05)$ decreases in PLT count, compared with the normal control. The results are presented in Table 4.

\section{Discussion}

Arsenic exposure via consumption of contaminated water has been reported to elevate pro-inflammatory mediators and lower anti-inflammatory IL-10 in circulation, which may cause various diseases [32,33].

In the present study, continuous administration of sodium arsenite alone caused significant increases in hepatic concentrations of the pro-inflammatory cytokines, TNF- $\alpha$ and IL- $1 \beta$ as well as significant increases in hepatic concentrations of the anti-inflammatory cytokines, IL-4 and IL-10, compared with the normal control. Pro-inflammatory cytokines such as TNF- $\alpha$ and IL-1 $\beta$ participate in the induction, amplification and perpetuation of inflammation. Continuous stimulated production of pro-inflammatory cytokines culminates in chronic inflammation [34,35], which has been implicated in the etiology of various disease conditions $[8,9]$. Conversely, anti-inflammatory cytokines, such as IL-10 and IL-4, mitigate the inflammatory process by regulating the activities of pro-inflammatory cytokines, thus putting a check to their activities [34-36]. This study therefore affirms that induction of inflammation is one of the various mechanisms involved in sodium arsenite-induced toxicity in experimental rats, by up-regulating the production of pro-inflammatory cytokines. The induction of IL-10 and IL-4 observed in this study may be an adaptive response in trying to curb the activities of TNF- $\alpha$ and IL- $1 \beta$. This is because; IL-10 represses the expression of inflammatory cytokines like TNF- $\alpha$, IL-6 and IL- 1 by activated macrophages. It can also enhance the expression / production of endogenous anti-inflammatory cytokines and down-regulate pro-inflammatory cytokine receptors thereby counterregulating the production and function of pro-inflammatory cytokines at several levels [34,37]. Interleukin-4 (IL-4) reduces the effects of IL-1 and TNF- $\alpha$ by affecting activated macrophages and inhibits the generation of free radicals [37]. The findings from this study agree with previous studies on the effect of sodium arsenite on pro-inflammatory and anti-inflammatory cytokines [10,38,39].

Post-treatment with ESEIG at various doses produced significant decreases in all assayed cytokines in dose-dependent and independent manner, compared with group 2, except IL-1ß. Simultaneous treatment with ESEIG followed similar trend except IL-4 and IL-10. In addition, treatment with ESEIG only at various doses produced similar results as those of the control, except IL-4. This indicates the mitigation of sodium SA-induced inflammation by ESEIG which may be as a result of its constituent anti-inflammatory and antioxidant phytochemicals [25].

Blood tissue is a pathological reflector of the health status of animals exposed to toxicants and other conditions [40]. Changes in hematological indices are useful in determining stresses orchestrated by environmental, nutritional and pathological factors [12]. The interaction of a toxin or its metabolites with cellular constituents may culminate in perturbations in hematological parameters [41], that indicate hematological disorders such as anemia (low hemoglobin content), leukopenia (reduced white blood cells), thrombocytopenia (low blood platelet level) [42-44]. Thus, hematological parameters are very useful in assessing toxicity and health / physiological status of animals [11,45].

In the present study, administration of sodium arsenite alone caused significant decreases in RBC, HB, PCV, MCH, MCHC and MCV, compared with normal control. Red blood cells (RBCs) facilitate transport of dissolved oxygen due to their constituent hemoglobin [46]. The significant decrease in RBC may be as a result of the cytotoxic effect of sodium arsenite that could have disrupted the red cell membrane integrity by lipid peroxidation and may climax in anemia, since a decreased RBC count is a sign of anemia [47,48]. As reported by Reddy and co-workers, an increase in the rate of hemoglobin destruction, or a decrease in the rate of hemoglobin synthesis may have influenced the significant decrease in HB concentration observed in this study [49]. This may have also contributed to the significant decreases in PCV, 
MCHC, MCH and MCV observed in this study and may connote the presence of hypochromic and microcytic anemia. Packed cell volume (PCV) is the percentage of the RBC volume of the whole blood volume [46]. Abnormally low PCV may be due to a decrease in RBC count, a decrease in HB concentration in each RBC or both. It can be caused by chemicalinduced damage to myeloid tissue which inhibits enzymes that are vital for hematopoiesis [41]. A possible inhibition of essential hematopoietic enzymes and destruction of RBCs by sodium arsenite may be responsible for the significant decrease in PCV. Similar findings have been reported in cadmium-intoxicated rats [50].

Administration of sodium arsenite alone also produced a significant decrease in blood platelets level, compared with control. This could inhibit the formation of platelet plugs that are vital in the prevention of haemorrhage at the site of injuries as well as loss of capillaries integrity [51]. In addition, administration of sodium arsenite alone caused significant increases in WBC count, lymphocytes, monocytes, basophils, eosinophils and neutrophils, compared to control. These may be indicative of sodium arsenite-induced leukocytosis, lymphocytosis, monocytosis, basophilia, eosinophilia and neutrophilia. White blood cells (leukocytes) provide immunity against antigen invasion. The significant increase in WBC may be as a result of the necrotic activities of sodium arsenite in the cells, as reported by Rousselot et al. [52] and Kumar et al. [53]. It could also be due to an increase in immune function as an attempt to mitigate the damaging effect of sodium arsenite [54]. This corroborates findings from some previous studies [53,55].

Cytokines and oxidative stress have been reported to enhance the activation of polymorpho- and mononuclear leukocytes [56,57]. Neutrophils are granular leukocytes that make up the highest percentage of leukocytes in circulation. Tissue injury and infection are common causes of elevated blood neutrophils [41]. Elevated neutrophils may be as a result of enhanced activities of leptin and leptin receptor that stimulates hematopoiesis [58]. Other causes of neutrophilia include necrosis and inflammation. Furthermore, inflammation and hepatitis have been reported to cause monocytosis and lymphocytosis, respectively and some forms of cancers have also been reported to cause eosinophilia and basophilia [41]. Inorganic arsenic compounds have also been reported to induce oxidative stress (which promotes carcinogenesis) by inhibiting antioxidant enzymes [59]. Thus, sodium arsenite might have caused the observed leukocytosis in this study via the induction of oxidative stress. Sodium arsenite and arsenic-induced hematological perturbations have also been reported by various researchers $[10,13,14]$.

Treatment with ESEIG simultaneously and two weeks after (post-treatment) caused significant increases in RBC, HB, PCV, MCH, MCHC and MCV, compared with group 2, that received sodium arsenite only. It also produced significant increases in platelets count in a dose-dependent manner as well as significant decreases in WBC count, lymphocytes, eosinophils and neutrophils, compared with group 2 (administered sodium arsenite only). Treatment with same extract led to no significant differences in monocyte and basophil counts, compared with group 2, administered sodium arsenite only. Thus, ESEIG may have ameliorated the hematotoxic effects of sodium arsenite by mitigating sodium arseniteoxidative stress. This may be due to the actions of antioxidant phytochemicals inherent in the extract [25]. Administration of ESEIG alone at the various doses, also produced significant increases in WBC, platelets, lymphocytes, monocytes, eosinophils and neutrophils, compared with control. This is suggestive of its involvement in hematological perturbations when administered singly on chronic basis. Similar findings have been reported in a previous study [60].

\section{Conclusion}

The results from the present study suggest that ethanol stem bark extract of $I$. gabonensis has anti-inflammatory and hemomodulatory properties against sodium arsenite-orchestrated inflammation and hematological perturbations in Wistar rats. Caution in its use is however advised as its long-term administration may be slightly toxic.

\section{Compliance with ethical standards}

\section{Acknowledgments}

Authors appreciate Derindam Research Institute of Biotechnology, Akwa Ibom State, Nigeria for allowing the use of their laboratories for this study.

\section{Disclosure of conflict of interest}

Authors Efosa Godwin Ewere, Ngozi Paulinus Okolie, Jessie Idongesit Ndem and Samson Adewale Oyebadejo have declared that no competing interest exists. 


\section{Statement of ethical approval}

All authors hereby declare that the "Principles of laboratory animal care" (NIH publication No. 85-23, revised 1985) were followed as well as specific national laws where applicable. All experiments have been examined and approved by the appropriate Institutional Review Board.

\section{References}

[1] Pandey PK, Yadav S, Nair S, Bhui A. Arsenic Contamination of the Environment: A New Perspective from CentralEast India. Environment International. 2002; 28: 235-45.

[2] Garba ZN, Gimba CE, Galadima A. Arsenic Contamination of Domestic Water from Nothern Nigeria. International Journal of Science and Technology. 2012; 2(1): 55-60.

[3] Ezeabasili ACC, Anike OL, Okoro BU, Dominic CM. Arsenic Pollution of Surface and Subsurface Water in Onitsha, Nigeria. African Journal of Environmental Science and Technology. 2014; 8: 491-497.

[4] Smith AH, Goycolea M, Haque R, Biggs ML. Marked increase in bladder and lung cancer mortality in a region of northern Chile due to arsenic in drinking water. American Journal of Epidemiology. 1998; 147: 660-669.

[5] Chiou HY, Chiou ST, Hsu YH, Chou YL, Tseng CH, Wei ML et al. Incidence of translational cell carcinoma and arsenic in drinking water: a follow-up study of 8,102 residents in an arseniasis-endemic area in northeastern Taiwan. American Journal of Epidemiology. 2001; 153(5): 411-418.

[6] Gulati K, Guhathakurta S, Joshi J, Rai N, Ray A. Cytokines and their Role in Health and Disease: A Brief Overview. MOJ Immunology. 2016; 4(2): 00121.

[7] Shaikh PZ. Cytokines and their physiologic and pharmacologic functions in inflammation: A review. International Journal of Pharmacy and Life Sciences. 2011; 2: 1247-1263.

[8] Ahmed AU. An overview of inflammation: mechanism and consequences. Frontiers in Biology. 2011; 6: 274-281.

[9] Landskron G, Dela-Fuente M, Thuwajit P, Thuwajit C, Hermoso MA. Chronic Inflammation and Cytokines in the Tumor Microenvironment. Journal of Immunology Research. 2014; 1-19.

[10] Singh MK, Singh PK, Yadav SS, Singh US, Dwivedi P, Yadav RS. Attenuation of Arsenic-Induced Dyslipidemia by Fruit Extract of Emblica Officinalis in Mice. International Journal of Nutrition, Pharmacolacology and Neurology Dis, 2018; 8: 3-9.

[11] Togun VA, Oseni BSA, Ogundipe JA, Arewa TR, Hammed AA, Ajonijebu DC, et al. Effects of chronic lead administration on the haematological parameters of rabbits - a preliminary study Proceedings of the 41st Conferences of the Agricultural Society of Nigeria. 2007: 341.

[12] Afolabi KD, Akinsoyinu AO, Olajide R, Akinleye SB. Haematological parameters of the Nigerian local grower chickens fed varying dietary levels of palm kernel cake. Poljoprivreda. 2011; 17(1): 74-78.

[13] Caciari T, Capozzella A, Tomei F, Nieto HA, Desio S. Arsenic and peripheral blood count in workers exposed to urban stressors. Clinical Therapy. 2012; 163: 293-302.

[14] Ghosh S, Mishra R, Biswas S, Bhadra RK, Mukhopadhyay PK. Lipoic acid mitigates arsenic-induced hematological abnormalities in adult male rats. Iranian Journal of Medical Science. 2017; 42: 242-250.

[15] Lowe AJ, Gillies ACM, Wilson J, Dawson IK. Conservation genetics of Bush Mango from Central/West Africa: Implica-tions for RAPD analysis. Molecular Ecology. 2000; 9: 831 - 841.

[16] Anegbeh PO, Usoro C, Ukafor V, Tchoundjeu Z, Leakey RRB, Schreckenberg K. Domestication of Irvingia gabonensis 3: Phenotypic variation of fruits and Kernels in a Nigeria village. Agroforestry Systems. 2003; 58: 213218.

[17] Ajanohoun JE, Aboubakar N, Dramane K, Ebot ME, Ekpere JA, Enow-Orock EG, et al. Traditional Medicine and Pharmacopoeia: Contribution to Ethnobotanical and Floristic Studies in Cameroon". Porto-Novo, Benin, OAU/STRC. 1996.

[18] Kuete V, Wabo GF, Ngameni B, Mbaveng AT, Metuno R, Etoa FX, et al. Antimicrobial Activity of the Methanolic Extract, Fractions and Compounds from the Stem Bark of Irvingia gabonensis (Ixonanthaceae). Journal of Ethnopharmacology. 2007; 114: 54-60. 
[19] Hubert DJ, Wabo FG, Ngameni B, Ngheguin TF, Tchoukoua A, Ambassa P, et al. In vitro Hepatoprotective and Antioxidant Activities of the Crude Extract and Isolated Compounds from Irvingia gabonensis. Asian Journal of Traditional Medicine. 2010; 5: 79-88.

[20] Etta HE, Olisaeke CC, Iboh CI. Effect of Irvingia gabonensis (Aubry-Lecomte ex O'Rorke) Seeds on the Liver and Gonads of Male Albino Rats. Journal of Biology, Agriculture and Healthcare. 2014; 4: 10-15.

[21] Omonkhua AA, Onoagbe IO. Effects of long-term oral administration of aqueous extracts of Irvingia gabonensis bark on blood glucose and liver profile of normal rabbits. Journal of Medicinal Plant Research. 2012; 6: 2581-2589.

[22] Omonkhua AA, Onoagbe IO, Fajimey IA, Adekola MB, Imoru ZA. Long-term anti-diabetic and anti-hyperlipidaemic effects of aqueous stem bark extract of Irvingia gabonensis in streptozotocin-induced diabetic rats. Biokemistri. 2014; 2: 1-8.

[23] Ojo OA, Ajoboye BO, Oyinloye BE, Ojo AB. Prophylactic Effects of Ethanolic Extract of Irvingia gabonensis Stem Bark against Cadmium-induced Toxicity in Albino Rats. Advanced Pharmaceutical Bulletin. 2014; 1-8.

[24] Nubila T, Ukaejiofo EO, Nubila NI, Shu EN, Okwuosa CN, Okofu MB, et al. Sub-acute effects of crude methanolic leaf extract of Irvingia gabonensis (Aubry- Lecomte et O'Rorke Baill) on activated partial thromboplastin time, prothrombin time and platelet values in albino wistar rats. Nigerian Journal of Experimental and Clinical Biosciences. 2014; 2(2): 75-78.

[25] Ewere EG, Okolie NP. Phytochemicals, Antioxidant Activity and Acute Toxicity of Ethanol Stem Bark Extract of Irvingia gabonensis O’Rorke Baill. EC Pharmacology and Toxicology. 2018; 6(6): 390-399.

[26] Ewere EG, Okolie NP, Etim OE, Oyebadejo SA. Mitigation of Arsenic-induced Increases in Pro-Inflammatory Cytokines and Haematological Derangements by Ethanol Leaf Extract of Irvingia gabonensis. Asian Journal of Research in Biochemistry. 2020; 7(1): 36-47.

[27] Ochei J, Kolhatkar A. Medical laboratory sciences: Theory and practice, New York, Tata McGraw Hill. 2008.

[28] Tietz NW. Fundamentals of clinical chemistry, W.B. Saunders, Philadelphia, PA. 1976; 897.

[29] Cheesbrough M. District laboratory practice in tropical countries Part 1 and 2, United Kingdom, Cambridge University Press. 2004.

[30] Dacie JV, Lewis SM. Practical haematology, 3rd ed. Churchill, London. 1963.

[31] Jain NCS. Schalm's Veterinary Haematology 4th Ed, Philadephia, Lea and Febigar. 1986.

[32] Druwe IL, Sollome JJ, Sanchez-Soria P, Hardwick RN, Camenisch TD. Arsenite activates NFkB through induction of C-reactive protein. Toxicology and Applied Pharmacology, 2012; 261: 263-270.

[33] Sinha D, Mukherjee B, Bindhani B, Dutta K, Saha H, Prasad P, Ray MR. Chronic low level arsenic exposure inflicts pulmonary and systemic inflammation. Journal of Cancer Science and Therapy, 2014; 6: 062-069.

[34] Zhang JM, An J. Cytokines, Inflammation and Pain. International Anesthesiology Clinics. 2007; 45: 27-37.

[35] Barnes PJ. The cytokine network in asthma and chronic obstructive pulmonary disease. Journal Clinical Investigations. 2008; 118: 3546-3556.

[36] Wojdasiewicz P, Poniatowski AA, Szukiewicz D. The Role of Inflammatory and Anti-Inflammatory Cytokines in the Pathogenesis of Osteoarthritis. Mediators of Inflammation. 2014; 1-19.

[37] Oliveira PA, Colaço A, Chaves R, Guedes-Pinto H, DelaCruz LF, Lopes C. Chemical carcinogenesis. Annals of the Brazilian Academy of Sciences. 2007; 79: 593-616.

[38] Alaqeel NK. Carnosine Treatment Attenuates Testicular Toxicity Induced by Arsenic in Rats. Life Science Journal. 2017; 14: 35-40.

[39] Yu N, Pei H, Huang Y, Li Y. (-)-Epigallocatechin-3-Gallate Inhibits Arsenic-Induced Inflammation and Apoptosis through Suppression of Oxidative Stress in Mice. Cellular Physiology and Biochemistry. 2017; 41: 1788-1800.

[40] Olafedehan CO, Obun AM, Yusuf MK, Adewumi 00, Oladefedehan AO, Awofolaji AO et al. Effects of residual cyanide in processed cassava peal meals on haematological and biochemical indices of growing rabbits. Pcoceedings of 35th annual conference of Nigerian society for animal production. 2010; 212.

[41] Arika WM, Nyamai DW, Musila MN, Ngugi MP, Njagi ENM. Hematological Markers of In vivo Toxicity. Journal of Hematology and Thromboembolic Disease. 2016; 4(2): 236. 
[42] Price EA, Schrier SL. Anemia in the elderly: introduction. Seminars in Hematology. 2008; 45: $207-209$.

[43] Bradbury C, Murray J. Investigating an incidental finding of thrombocytopenia. BMJ. 2013; 346: f11.

[44] Izak M, Bussel JB. Management of thrombocytopenia. F1000Prime Reports. 2014; 6: 45.

[45] Pankaj PP, Varma MC. Potential role of Spirulina platensis in maintaining blood parameters in alloxan induced diabetic mice. International Journal of Pharmacy and Pharmaceutical Science. 2013; 5: 450-456.

[46] Wintrobe MM, Greer JP. Wintrobe’s Clinical Hematology, Philadelphia, Lippincott Williams and Wilkins. 2009.

[47] Kolanjiappan K, Manoharan S, Kayalvizhi M. Measurement of erythrocyte lipids, lipid peroxidation, antioxidants and osmotic fragility in cervical cancer patients. Clinica Chimica Acta. 2002; 326: 143-149.

[48] Junqueira LC, Carneiro J, Kelley RO. Basic Histology. A Lange Medical Book 7th ed, Appleton and Lange. 2006.

[49] Reddy PM, Bashamohideen M. Fenvalerate and Cypermethrin Induced Changes in the Haematological Parameters of Cyprinu carpio. Acta Hydrochimica Hydrobiologica. 1989; 17: 101-107.

[50] Ewere EG, Etim OE, Oyebadejo SA, Edem BV. Attenuation of Cadmium-Induced Haematological Derangements in Wistar Albino Rats by Irvingia gabonensis O’Rorke Baill Ethanol Leaf Extract. European Journal of Biomedical and Pharmaceutical Sciences. 2017; 4: 169-174.

[51] Hounkpatin ASY, Johnson RC, Guédénon P, Domingo E, Alimba CG, Boko M, et al. Protective Effects of Vitamin C on Haematological Parameters in Intoxicated Wistar Rats with Cadmium, Mercury and Combined Cadmium and Mercury. International Research Journal of Biological Sciences. 2012; 1: 76-81.

[52] Rousselot P, Larghero J, Lambaune S, Poupon J, Chopin M, Dosquet C, et al. Arsenic trioxide is effective in the treatment of multiple myeloma in SCID mice. European Journal of Haematology. 2004; 72: 166-171.

[53] Kumar AV, Madhusudhana C, Kishore S. Hematological alterations induced by Sodium arsenate toxicity in Albino mice. International Journal of Pharmaceutical Life Sciences. 2015; 6: 4166-4170.

[54] Mishra A, Niyogi PA. Haematological changes in the Indian Murrel (Channa punctatus, Bloch) in response to phenolic industrial wastes of the Bhilai steel plant (Chhaittisgarh, India). International Journal of Research in Chemistry and Environment. 2011; 1: 83-91.

[55] Adakole J. Changes in some haematological parameters of the African catfish (Clarias gariepinus) exposed to a metal finishing company effluent. Indian Journal of Science and Technology. 2012; 4: 2510-2514.

[56] Scherberich JE. Proinflammatory blood monocytes: main effector and target cells in systemic and renal disease; background and therapeutic implications. International Journal of Clinical Pharmacology and Therapy. 2003; 41: 459-464.

[57] Shurtz-Swirski R, Sela S, Herskovits AT, Shasha SM, Shapiro G, Nasser L et al. and Kristal B. Involvement of peripheral polymorphonuclear leukocytes in oxidative stress and inflammation in type 2 diabetic patients. Diabetes Care. 2004; 24(1): 104-110.

[58] Peelman F, Waelput W, Iserentant H, Lavens D, Eyckerman S, Zabeau L, et al. and Tavernier J. Leptin: linking adipocyte metabolism with cardiovascular and autoimmune diseases. Progress in Lipid Research. 2004; 43(4): 283-301.

[59] Waalkes MP, Liu J, Ward JM, Diwan LA. Mechanisms underlying arsenic carcinogenesis: hypersensitivity of mice exposed to inorganic arsenic during gestation. Toxicology and Industrial Health. 2004; 198: 31-38.

[60] Ewere EG, Okolie NP, Eze GI, Oyebadejo SA. Effect of Irvingia gabonensis Stem Bark on Liver Function in Sodium Arsenite-Exposed Wistar Rats. Journal of Asian Scientific Research. 2019; 9(8): 81-94. 